\title{
PREVALENSI DAN FAKTOR RISIKO TUNGAU DEBU RUMAH DI PAMULANG (TANGERANG) DAN PASAR REBO (JAKARTA)
}

\author{
Rizal Subahar* Widiastuti* Agus Aulung* \\ Departemen Parasitologi, Fakultas Kedokteran UniversiasIndonesia, Jl. Salemba Raya No.6 \\ Jakarta 10430, Indonesia.
}

\begin{abstract}
Abstrak
Tungau debu rumah (TDR) merupakan aeroallergen yang dapat ditemukan di berbagai bagian rumahperkotaan terutama kasur, sehingga faktor risiko tersebut mempengaruhi angka prevalensi TDR. Tujuan penelitian ini ialah mempelajari prevalensi dan faktor risiko TDR di daerah perkotaan, yaitu Pamulang (Tangerang Selatan) dan Pasar Rebo (Jakarta Timur). Rancangan penelitian ini adalah cross-sectional. Sampel debu rumah dikumpulkan dari rumah responden lantai ruang tamu, lantai kamar tidur, lantai ruang dapur, lantai ruang teras, ventilasi,kasur kapuk, sofa, spring bed, kasur busa, dan karpet. Tungau diperiksa dengan metode langsung. TDR yang ditemukan ialah Dermatophagoides pteronyssinus, D.farinae, dan Glyciphagus destructor. Angka prevalensi TDR yang ditemukan adalah 66,9\% (621/927). Secara statistik, tidak ditemukan perbedaan yang bermakna ( $>00,05)$ antara prevalensi TDR di Pamulang $(59,8 \%, 307 / 513)$ dan Pasar Rebo $(75,8 \%, 314 / 414)$. Rumah responden yangpositif (+) TDR adalah 94.2\% (49/52) di Pamulang dan 63.6\% (28/44) di Pasar Rebo. Kasur dan lantai tempat tidur merupakan faktor risiko TDR (OR=1.99 95\% CI 1.06-3.72 dan $\mathrm{OR}=1.8$ 95\% CI 1.10-2.90). Penelitian ini memperlihatkan bahwa rumah-rumah di dua daerah perkotaan tersebut ditemukan TDR yang berlimpah.
\end{abstract}

Kata kunci: tungau debu rumah, prevalensi, faktor risiko, Pamulang, Pasar Rebo

\section{Abstract}

House dust mites (HDM), anaeroallergen which may be found in all of part of the urbanhouseincluding mattress. The objectives of this study were to find out the prevalence and risk factors of house dust mites in urban communities i.e.,Pamulang (Southern Tangerang) and Pasar Rebo (Nothern Jakarta). The studydesign was a cross-sectional study. The samples of house dusts were collected from house of respondents, living-room floors, bed-room floors, kitchen-room floors, terrace-room floors, ventilation, kapuk mattress, sofa, spring bed, foam mattress, and carpet. Mites were examined by a direct method. The species of HDMfound wereDermatophagoides pteronyssinus, D.farinae, and Glyciphagus destructor. The prevalence rate ofHDMwas 66,9\% (621/927). Statistically, no significant difference $(p>0,05)$ was found between the prevalence of HDM in Pamulang $(59,8 \%, 307 / 513)$ and Pasar Rebo (75,8\%, 314/414). In Pamulang, 94.2\% (49/52) of the respondent's houses were HDM positive (+) and 63.6\% (28/44) in Pasar Rebo. Mattresses and bed-room floors were risk factors for $\operatorname{HDM}(O R=1.9995 \%$ CI 1.06-3.72 and $O R=1.895 \%$ CI 1.10-2.90). This study showed that the houses in two urban communities hadrich HDM.

Key words; house dust mite, prevalence, risk factor, Pamulang, Pasar Rebo

Makalah ini telah dipresentasikan dalam acara ACTMP ke-7, Malang, Jawa Timur, pada 1720 Mei 2016. 


\section{PENDAHULUAN}

Distribusi tungau debu rumah (TDR) yang merupakan aeroallergen tersebar luas di seluruh dunia, baik di negara dengan iklim dingin, subtropis, dan tropis. Prevalensi untuk masing-masing spesies TDR tersebut bervariasi bergantung pada suhu dan kelembapan, sebagai contoh di Polandia, Eropa dengan iklim dingin, prevalensi D. farinae lebih besar $(58,9 \%)$ dibandingkan dengan spesies TDR lainnya karena kelembapan di Eropa sebesar 50\% cocok untuk perkembangan D. farina (Henzel et al, 2010). Negara tropis seperti Indonesia memiliki prevalensi D. pteronyssinus lebih besar dibandingkan spesies TDR lainnnya(Aulung dkk.1987, Thomas 2010).

Spesies TDR yang penting sebagai salah satu pencetus penyakit alergi pada manusia adalahDermatophagoides pteronyssinus, D. farinae, dan Glyciphagus destructor (Thomas et al. 2002), diduga berkontribusi terhadap peningkatan pevalensi penyakit alergi, terutama asma di negara berkembang sebesar 5-30\% dalam 50 tahun terakhir ini (Asher et al. 2006). Tingkat morbiditas penyakit alergi tersebut semakin tinggi akibat terpapar konsentrasi aeroallergen TDR (Brusee et al 2005, Jacquet et al. 2009, Arshad et al.2010, Calsten et al. 2011). TDRdikenal sebagai aeroallergenyang potensialbagi individu yang sensitif terhadap alergi debu rumah, seperti individu dengan penyakit asmayang mengakibatkan deskuamasi sel epitel saluran pernapasan dan menghasilkan sitokin proinflamasi, yaitu IL6 dan IL8 (Natalia,2015). TDR juga dapat mensensitisasi penyakit alergi lainnya, seperti rinitis eksem atopi atau sindrom dermatitis.TDR dapat ditemukan pada debu di berbagai bagian rumah, seperti debu ruang tamu, kamar tidur, dapur, tempat tidur, karpet, bangku sofa, ventilasi, dan lain-lain. Kasur dan bantalmerupakan faktor risiko yang signifikan dibandingkan tempat lainnya di dalam rumah (Custovic et al 1996). Pada saat manusia tidur maka serpihan kulit manusia tertinggal di kasur dan bantal. Serpihan kulit manusia tersebut merupakan sumber makanan untuk TDR, oleh karena itu kasur dan bantal merupakan habitat yang cocok untuk
TDR. Ventilasi rumah mempengaruhi suhu dan kelembapan di sekitar rumah sehingga ventilasi juga merupakan faktor risiko keberadaan TDR (Wright et al.2009). Sikap dan perilaku penduduk seperti membersihkan kamar tidur, ruang tamu, menjemur kasur, dan mengganti alas tidur dan bantal juga merupakan faktor risiko keberadaan TDR. Faktor-faktor risiko tersebut dapat ditemukan di daerah perkotaan sehingga mempengaruhi prevalensi TDR.

Indonesia merupakan daerah tropis dengan suhu rata-rata 25-30oC dan kelembapan sekitar $70-90 \%$ dimana suhu dan kelembapan tersebut cocok untuk pertumbuhan dan perkembangan TDR. Meskipun demikian, data distribusi spesies TDR di beberapa Provinsi Indonesia belum tersedia atau belum dilaporkan. Baratawidjaja dkk. (1998) menemukan prevalensi D. farinae sebesar 39\% dan $25 \%$ D. pteronyssinus di Jakarta. Temuan ini tidak sesuai dengan kelembapan di Jakarta yang tinggi (Thomas, 2010). D.pteronyssinus merupakan spesies TDR yang dominan di Bali (Santoso, 1998). Spesies TDR lainnya, yaitu Blomia tropicalis ditemukan di Indonesia (Thomas, 2010).

Sampai saat ini, TDR menarik perhatian untuk penelitian epidemiologi dari aspek prevalensi dan faktor risiko terutama di daerah perkotaan. Penduduk di daerah perkotaan memiliki keragaman suku, budaya, agama, sikap, dan perilaku yang berbeda. Status kependudukan di daerah perkotaan terdiri atas penduduk tetap dan tidak tetap (kontrakan). Gaya hidup di daerah perkotaan tersebut, seperti karakteristik rumah, status rumah, penggunaan kasur, karpet, dan sofa merupakan faktor risiko keberadaan TDR. Status rumah kontrakan tersebut penting untuk distribusi TDR karena penduduk dengan status kontrakan melakukan perpindahan dari satu tempat ke tempat lainnya setelah masa kontrakan tersebut habis. Perpindahan penduduk tersebut juga menyebabkan perpindahan TDR ke tempat lainnya. Selain itu, suhu dan kelembapan udara di daerah perkotaan mempengaruhi perkembangan TDR. Oleh karena itu, penelitian ini dilakukan di dua daerah perkotaan, yaitu Pamulangyang terletak di Tangerang Selatan dan Pasar Rebo di Jakarta Timur.Rata-rata suhu dan kelembapan udara di dua lokasi tersebut adalah 25-35oC dan 70-90\%. 
Penelitian ini bertujuan untuk mengetahui prevalensi dan faktor risiko TDR pada penduduk perkotaan di Pamulang dan Pasar Rebo.

\section{METODE PENELITIAN}

Penelitian ini dilakukan dengan menggunakan rancangan cross-sectional. Penelitian dilakukan di dua lokasi perkotaan, yaitu Pamulang dan Pasar Rebo. Pamulang terletak di Tangerang Selatan, Provinsi Banten. Pasar Rebo terletak di Jakarta Timur, Provinsi DKI Jakarta. Responden adalah kepala keluarga (KK) dengan status penduduk tetap dan tidak tetap.Data demografi responden dikumpulkan dengan wawancara dengan menggunakan kuesioner yang telah distandardisasikan. Kuesioner tersebut meliputi data identitas, tingkat sosial-ekonomi, pendidikan, riwayat penyakit asma, status rumah, jumlah kamar rumah, jenis lantai rumah, jenis kasur, jumlah ventilasi, dan frekeunsi membersihkan rumah. Tim Peneliti melakukan wawancara secara langsung dengan responden. Sampel debu diambil dari rumah responden tersebut. Lokasi pengambilan debu rumah ialah kamar tidur, tamu, dapur, dan teras. Selain itu, debu diambil dari kasur, karpet, sofa, dan ventilasi rumah. Debu rumah diambil dengan menggunakan sikat.Luas tempat pengambilan debu, yaitu $1 \mathrm{~m} 2$ untuk kamar, dan kurang dari 1 m2untuk kasur, karpet, dan sofa. Debu yang terkumpul dimasukkan ke dalam kantong plastik yang telah diberi label, yaitu label nomor sampel, tanggal, dan tempat pengambilan. Suhu dan kelembapan rumah diukur dengan menggunakan termometer.

Debu tersebut dibawa ke laboratorium Departemen Parasitologi, Fakultas Kedokteran, Universitas Indonesia. Pada hari yang sama, sampel debu diperiksa, jika tidak, sampel tersebut disimpan dalam lemari pendingin dengan suhu $-20 \circ C$. Pemeriksaan sampel debu untuk diagnosis tungau menggunakan teknik langsungdi bawah mikroskop,seperti yang telah dideskripsikan sebelumnya (Voorhorst et al. 1969 dan Aulung et al. 1986). Untuk identifikasi spesies tungau, jarum digunakan untuk mengisolasi tungau dari sampel debu dan tungau tersebut diletakkkan di atas kaca objek. Selanjutnya, sediaan tungau tersebut ditambahkan asam laktat 90\% (2-3 tetes) dan larutan Hoyer's. Spesies tungau diidentifikasikan berdasarkan ciri-ciri morfologinya,seperti yang telah dideskripsikan oleh Krantz and Walter.

Jika di dalam sampel debu ditemukan tungau, sampel tersebut dicatat sebagai debu yang positif $(+)$. Angka prevalensi didapatkan dengan rumus; Prevalensi $=$ sampel debu $(+)$ tungau/total sampel debu yang diperiksa x 100\%

Analisis data demografi dilakukan dengan menggunakan statistik deskriptif, yaitu Crosstabs untuk membandingkan data demografi responden (jenis kelamin, usia,suku, pekerjaan, pendidikan, pendapatan, dan riwayat penyakit alergi) di Pamulang dan Pasar Rebo.Variabel bebas yang digunakan ialah status rumah (kontrakan dan pribadi), jumlah ventilasi ( $>4$ dan $<4)$ dan jenis lantai (keramik dan nonkeramik) dan masing-masingvariabel dibagi ke dalam dua kategori. Variabel terikat ialah tungau yang juga dikategorikan menjadi dua;positif $(+)$ dan negatif (-). Untuk mengetahui perbedaan tungau yang ditemukan pada rumah pribadi dan kontrakan dilakukan analisis statistik nonparametrik, yaitu uji chi-sqaureantara variabel status rumah dengan tungau. Analisis uji chi-square yang sama dilakukan antara jenis lantai dan jumlah ventilasi dengan tungau. Nilai ORdari jenis kasur didapatkan dari uji chi-squareantara variabel jenis kasur (alami dan nonalami) dengan tungau ( + dan -). Tingkat kesalahan $(\alpha)=0,05$. Semua proses analisis statistik dilakukan dengan Program SPSS ver.17.

\section{HASIL DAN DISKUSI}

Jumlah responden yang berpartisipasi dalam penelitian ini adalah 96 orang yang terdiri atas 52 orang di Pamulang dan 44 orang di Pasar Rebo. Total debu rumah yang diperiksa sebanyak 927 sampel debu (513 sampel di Pamulang dan 414 sampel Pasar Rebo) dan jumlah TDR yang ditemukan sebanyak 621. Prevalensi TDR pada penelitian ini secara keseluruhan di dua lokasi penelitian adalah sebesar66,9\% (621/927). Prevalensi TDR di Pamulang sebesar 59,8\% (307/513) dan di Pasar Rebo 75,8\% (314/414). Secara statistik, tidak ditemukan perbedaan 
yang bermakna $(\mathrm{p}>0,05)$ antara prevalensi TDR di Pamulang dan Pasar Rebo. Rumah responden yang positif (+) TDR adalah sebanyak 49 rumah (94,2\%) di Pamulang dan 28 rumah $(63,6 \%)$ di Pasar Rebo. Spesies TDR yang ditemukan dalam penelitian ini ialahD. pteronyssinus, G.destructor, dan D. farinae. Secara total di Pamulang dan Pasar Rebo prevalensi D. pteronyssinusadalah 60,4\% (58 rumah), G. destructoradalah 20,8\% (20 rumah), dan D. farinaeadalah 4,2\% (4 rumah).

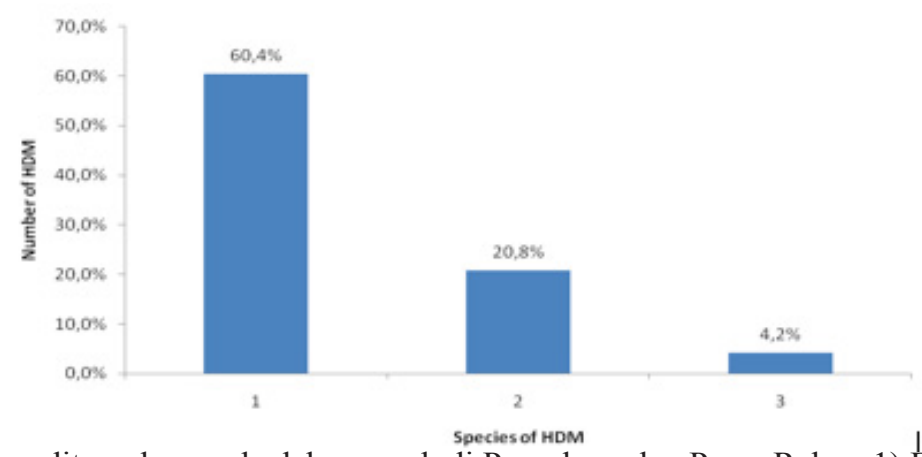

Grafik 1. TDR yang ditemukan pada debu rumah di Pamulang dan Pasar Rebo. 1) D.pteronyssinus $(60.4 \%, 58 / 96)$ 2) D.farinae $(20.8 \%, 20 / 96), 3)$.

G.destructor $(4,2 \%, 4 / 96)$.

Tabel 1 memperlihatkan karakteristik demografi responden. Pada umumnya, responden dalam penelitian ini adalah ibu rumah tangga dibandingkan bapak di kedua lokasi penelitian. Umur responden lebih dari 30 tahun. Di Pamulang, responden dari suku betawi lebih banyak dibandingkan suku lainnya, sedangkan di Pasar Rebo, responden lebih banyak suku jawa. Pada umumnya, di dua lokasi penelitian, sebagian besar responden bekerja sebagai Non PNS dibandingkan PNS. Tingkat pendidikan responden termasuk kategori rendah. Selain itu, pendapatan responden juga rendah.

Tabel 1.Karakteristik Demografi Responden di Pamulang dan Pasar Rebo

\begin{tabular}{|c|c|c|c|c|c|}
\hline \multirow[b]{2}{*}{ Variabel } & \multicolumn{2}{|c|}{ Pamulang } & \multicolumn{2}{|c|}{ Pasar Rebo } & \multirow[t]{2}{*}{$\mathrm{p}$} \\
\hline & $\mathrm{n}$ & $\%$ & $\mathrm{n}$ & $\%$ & \\
\hline Jenis Kelamin & & & & & 0,986 \\
\hline Laki-Laki & 19 & 36,5 & 16 & 36,4 & \\
\hline Perempua & 33 & 63,5 & 28 & 63,6 & \\
\hline Umur & & & & & 0,933 \\
\hline $20-30$ tahun & 11 & 21,2 & 9 & 20,5 & \\
\hline$>30$ tahun & 41 & 78,8 & 35 & 79,5 & \\
\hline Suku & & & & & 0,053 \\
\hline Jawa & 17 & 32,7 & 23 & 52,3 & \\
\hline Sunda & 7 & 13,5 & 4 & 9,1 & \\
\hline Betawi & 26 & 50 & 15 & 34,1 & \\
\hline Lain-lain & 1 & 3,8 & 2 & 4,5 & \\
\hline Pekerjaan & & & & & 0,592 \\
\hline PNS & 1 & 1,9 & 2 & 4,5 & \\
\hline Non-PNS & 51 & 98,1 & 42 & 95,5 & \\
\hline
\end{tabular}




$\begin{array}{lccccc}\text { Pendidikan } & & & & & 0,018 \\ \text { Tinggi } & 17 & 32,7 & 9 & 56,8 & \\ \text { Rendah } & 35 & 67,3 & 35 & 43,2 & \\ & & & & & \\ \begin{array}{l}\text { Pendapatan } \\ \text { Tinggi }\end{array} & 7 & 13,5 & 9 & 20,5 & 0,36 \\ \quad \text { Rendah } & 45 & 86,5 & 35 & 79,5 & \\ & & & & & 1,00 \\ \text { Riwayat Penyakit Alergi } & 4 & 7,7 & 3 & 6,8 & \\ \text { Ada } & 48 & 92,3 & 41 & 93,2 & \\ \text { Tidak ada } & & & & \end{array}$

Tabel 2.Keberdaan TDR yang ditemukan di Status rumah, Jenis Lantai dan Jumlah Ventilasi Rumah.

\begin{tabular}{lccccc}
\hline $\begin{array}{l}\text { Tempat ditemukan } \\
\text { TDR }\end{array}$ & \multicolumn{2}{c}{ Pamulang } & \multicolumn{2}{c}{ Pasar Rebo } & Nilai \\
\hline Status Rumah & + & - & + & - & p \\
$\quad$ Kontrakan & 3 & 5 & 14 & 4 & 0,119 \\
$\quad$ Pribadi & 32 & 12 & 20 & 6 & \\
& & & & & \\
& & & & & \\
Jenis Lantai & & & & & 0,139 \\
$\quad$ Keramik & 31 & 14 & 29 & 6 & \\
$\quad$ NonkKeramik & 4 & 3 & 5 & 4 & \\
Jumlah Ventilasi & & & & & \\
$<4$ & 19 & 12 & 18 & 7 & \\
$\geq 4$ & 16 & 5 & 16 & 3 & \\
\hline
\end{tabular}

Tabel 2 memperlihatkan bahwa di Pamulang dan Pasar Rebo ditemukan TDR pada rumah kontrakan dan pribadi responden. Jumlah rumah kontrakan yang positif TDR sedikit dibandingkan rumah pribadi, namun secara statistik tidak ditemukan perbedaan yang bermakna di kedua lokasi tersebut $(\mathrm{p}<0,05)$. Berdasarkan jenis lantai rumah, rumah dengan lantai keramik lebih banyak ditemukan TDR dibandingkan lantai nonkeramik, tetapi secara statistik tidak terdapat perbedaan yang bermakna $(\mathrm{p}>0,05)$. Selain itu, rumah responden dengan jumlah ventilasi kurang dari 4 ditemukan TDR lebih banyak dibandingkan ventilasi yang lebih dari 4, namun secara statistik tidak terdapat perbedaan yang bermakna ( $>00,05)$. Hal itu menunjukkan bahwa keberadaan TDR berlimpah di debu rumah, baik di lantai maupun ventilasi.

Di Pamulang,responden yang memiliki kasur kapuk, karpet, kasur busa, sofa, dan spring bed masingmasing adalah sebanyak 35 (30,2\%), $12(10,3 \%), 12(10,3 \%), 22(19,0 \%)$, dan 35 (30,2\%). Di Pasar Rebo, respondenyang memiliki kasur kapuk, karpet, kasur busa, sofa, spring bed masing-masing adalah sebanyak $21(23,1 \%), 12(13,2 \%), 13(14,3 \%), 22(24,1 \%)$, dan $23(25,3 \%)$. 
Tabel 3. Spesies Tunggal TDR yang ditemukan di Habitat Bahan Alami dan Nonalami

\begin{tabular}{|c|c|c|c|c|c|c|c|}
\hline \multicolumn{2}{|c|}{ Jenis Bahan } & \multicolumn{5}{|c|}{ Spesies Tunggal TDR } & \multirow[b]{3}{*}{$\mathrm{Gd}$} \\
\hline & & \multicolumn{3}{|c|}{ Pamulang } & \multicolumn{2}{|r|}{ Pasar Rebo } & \\
\hline & & Dp & Df & Gd & Dp & Df & \\
\hline Alami & $\begin{array}{l}\text { Kasur } \\
\text { Kapuk }\end{array}$ & $\begin{array}{c}16 \\
(72.7 \%, 16 / 22)\end{array}$ & $\begin{array}{c}0 \\
(0.0 \%, 0 / 22)\end{array}$ & $\begin{array}{c}3 \\
(13.6 \%, 3 / 22)\end{array}$ & $\begin{array}{c}7 \\
(58.3 \%, 7 / 12)\end{array}$ & $\begin{array}{c}0 \\
(0.0 \%, 0 / 12)\end{array}$ & $\begin{array}{c}0 \\
(0.0 \%, 0 / 12)\end{array}$ \\
\hline Nonalami & Karpet & $\begin{array}{c}4 \\
(50.0 \%, 4 / 8)\end{array}$ & $\begin{array}{c}1 \\
(12.5 \%, 1 / 8)\end{array}$ & $\begin{array}{c}1 \\
(12.5 \%, 1 / 8)\end{array}$ & $\begin{array}{c}2 \\
(66.7 \%, 2 / 3)\end{array}$ & $\begin{array}{c}0 \\
(0.0 \%, 0 / 3)\end{array}$ & $\begin{array}{c}0 \\
(0.0 \%, 0 / 3)\end{array}$ \\
\hline & Kasur Busa & $\begin{array}{c}2 \\
(100.0 \%, 2 / 2)\end{array}$ & $\begin{array}{c}0 \\
(0.0 \%, 0 / 2)\end{array}$ & $\begin{array}{c}0 \\
(0.0 \%, 0 / 2)\end{array}$ & $\begin{array}{c}3 \\
(50.0 \%, 3 / 6)\end{array}$ & $\begin{array}{c}0 \\
(0.0 \%, 0 / 6)\end{array}$ & $\begin{array}{c}3 \\
(50.0 \%, 3 / 6)\end{array}$ \\
\hline & Sofa & $\begin{array}{c}8 \\
(53.3 \%, 8 / 15)\end{array}$ & $\begin{array}{c}0 \\
(0.0 \%, 0 / 15)\end{array}$ & $\begin{array}{c}6 \\
(40.0 \%, 6 / 15)\end{array}$ & $\begin{array}{c}4 \\
(40.0 \%, 4 / 10)\end{array}$ & $\begin{array}{c}0 \\
(0.0 \%, 0 / 10)\end{array}$ & $\begin{array}{c}3 \\
(30.0 \%, 3 / 10)\end{array}$ \\
\hline & Spring bed & $\begin{array}{c}6 \\
(42.9 \%, 6 / 14) \\
\end{array}$ & $\begin{array}{c}0 \\
(0.0 \%, 0 / 15) \\
\end{array}$ & $\begin{array}{c}3 \\
(21.4 \%, 3 / 14) \\
\end{array}$ & $\begin{array}{c}2 \\
(25.0 \%, 2 / 8) \\
\end{array}$ & $\begin{array}{c}0 \\
(0.0 \%, 0 / 8) \\
\end{array}$ & $\begin{array}{c}0 \\
(0.0 \%, 0 / 8) \\
\end{array}$ \\
\hline Total & & 36 & 1 & 13 & 18 & 0 & 3 \\
\hline
\end{tabular}

Tabel 3 dan 4 memperlihatkan beberapa spesies tunggal TDR yang ditemukan pada habitat alami dan nonalami. Di kasur kapuk ditemukan spesies tunngal TDR paling banyak dibandingkan habitat lainnya di dua lokasi penelitian. Berdasarkan keberadaan spesies tunggal atau ganda TDR, di Pamulang ditemukan spesies tunggal dan campuran. Spesies tunggal hanya ditemukan D. pteronyssinus, sedangkan campuran terdiri atasD. pteronyssinus, D. farinae, dan G. destructor. Berbeda dari Pamulang, di Pasar Rebo hanya spesies tunggal, yaitu D. pteronyssinus atau G. destructor. Hal itu menunjukkan bahwa keberadaan spesies TDR berlimpah di dua lokasi penelitian dan spesies yang dominan adalah D. pteronyssinus.

Tabel 4. Spesies Ganda TDR yang ditemukan di Habitat Bahan Alami dan Nonalami

\begin{tabular}{|c|c|c|c|c|c|}
\hline \multicolumn{2}{|c|}{ Jenis Bahan } & \multicolumn{4}{|c|}{ Spesies Ganda TDR } \\
\hline & & \multicolumn{2}{|c|}{ Pamulang } & \multicolumn{2}{|c|}{ Pasar Rebo } \\
\hline & & \multirow{2}{*}{$\begin{array}{c}\text { Dp \& Df } \\
3 \\
3 \\
(4.5 \%, 1 / 22)\end{array}$} & \multirow{2}{*}{$\begin{array}{c}\mathrm{Dp} \& \mathrm{Gd} \\
2 \\
(4.5 \%, 1 / 22)\end{array}$} & \multirow{2}{*}{$\begin{array}{c}\text { Dp \& Df } \\
0 \\
(0.0 \%, 0 / 12)\end{array}$} & $\mathrm{Dp} \& \mathrm{Gd}$ \\
\hline Alami & $\begin{array}{l}\text { Kasur } \\
\text { Kapuk }\end{array}$ & & & & $\begin{array}{c}5 \\
(41.7 \%, 5 / 12)\end{array}$ \\
\hline \multirow[t]{4}{*}{ Nonalami } & Karpet & $\begin{array}{c}0 \\
(0.0 \%, 0 / 8)\end{array}$ & $\begin{array}{c}2 \\
(25.0 \%, 2 / 8)\end{array}$ & $\begin{array}{c}0 \\
(0.0 \%, 0 / 3)\end{array}$ & $\begin{array}{c}1 \\
(33.3 \%, 1 / 3)\end{array}$ \\
\hline & Kasur Busa & $\begin{array}{c}0 \\
(0.0 \%, 0 / 2)\end{array}$ & $\begin{array}{c}0 \\
(0.0 \%, 0 / 2)\end{array}$ & $\begin{array}{c}0 \\
(0.0 \%, 0 / 6)\end{array}$ & $\begin{array}{c}0 \\
(0.0 \%, 0 / 6)\end{array}$ \\
\hline & Sofa & $\begin{array}{c}0 \\
(0.0 \%, 0 / 15)\end{array}$ & $\begin{array}{c}1 \\
(6.7 \%, 1 / 15)\end{array}$ & $\begin{array}{c}0 \\
(0.0 \%, 0 / 10)\end{array}$ & $\begin{array}{c}3 \\
(30.0 \%, 3 / 10)\end{array}$ \\
\hline & Spring bed & $\begin{array}{c}0 \\
(0.0 \%, 0 / 14)\end{array}$ & $\begin{array}{c}5 \\
(35.7 \%, 5 / 15)\end{array}$ & $\begin{array}{c}0 \\
(0.0 \%, 0 / 8)\end{array}$ & $\begin{array}{c}6 \\
(75.0 \%, 6 / 8) \\
\end{array}$ \\
\hline Total & & 1 & 10 & 0 & 15 \\
\hline
\end{tabular}


Tabel 5 memperlihatkan bahwa habitat alamai, yaitu kasur kapuk yang digunakan oleh responden di Pamulang dan Pasar Rebo merupakan faktor risiko yang signifikan $(\mathrm{p}<0,05)$ untuk TDR. Hasil uji chisquare memperlihatkan 95\% dipercaya bahwa kasur kapuk meimiliki 1,99 kali berisiko ditemukan TDR dibandingkan dengan habitat nonalami.

Tabel 5. Faktor Risiko Habitat Alami dan Nonalami untuk TDR

\begin{tabular}{|c|c|c|c|c|c|}
\hline & \multicolumn{3}{|c|}{ TDR } & \multirow[b]{2}{*}{$\mathrm{p}$} & \multirow[b]{2}{*}{ OR $95 \% \mathrm{CI}$} \\
\hline & $(+)$ & $(-)$ & Total & & \\
\hline Alami & 34 & 22 & 56 & 0.03 & $1.99(1.06-3.72)$ \\
\hline Nonalami & 66 & 85 & 151 & & \\
\hline Total & 100 & 107 & 207 & & \\
\hline
\end{tabular}

Tabel 6 memperlihatkan frekuensi membersihkan kasur yang dilakukan oleh responden di Pamulang dan Pasar Rebo hanya 1 x sehari dan 2 x sehari. Meskipun frekuensi membersihkan kasur 1 x sehari, TDR masih ditemukan. Hasil uji statistik memperlihatkan tidak terdapat perbedaan yang bermakna $(\mathrm{p}>0,05)$ antara frekuensi membersihkan kasur $1 \times$ sehari dan $2 \times$ sehari terhadap keberadaan TDR. Hal itu menunjukkan polusi debu dengan keberadaan TDR tinggi di kasur tidak dapat diberantas hanya dengan membersihkan kasur.

Tabel 6. Hubungan Frekuensi Membersihkan kasur dengan Keberadaan TDR di Pamulang dan Pasar Rebo.

\begin{tabular}{lcccc}
\hline Frekuensi & \multicolumn{3}{c}{ Kembersihkan } & \multicolumn{2}{c}{ Keberadaan TDR } & Jumlah & Nilai \\
\cline { 2 - 3 } Kasur & Positif $(+)$ & Negatif $(-)$ & & p \\
\hline I x sehari & $35(36,5 \%)$ & $4(4,2 \%)$ & 39 & 0,23 \\
$2 x$ sehari & $46(47,9 \%)$ & $11(11,5 \%)$ & 57 &
\end{tabular}

\section{DISKUSI}

Tujuan penelitian ini adalah mengetahui prevalensi dan faktor-faktor risiko TDR pada penduduk perkotaan di Pamulang dan Pasar Rebo.Pada penelitian ini ditemukan prevalensi TDR yang tinggi. Prevalensi tersebut tidak berbeda jika dibandingkan dengan angka di negara berkembang dengan iklim tropik lainnya.Pada umumnya, di negara tropik ditemukan spesies TDR, yaitu D. pteronyssinus, D. farinae, dan G. destructor. Hasil penelitian ini sama seperti hasil penelitian lainnya yang dilakukan di negara tropik, seperti Meksiko, Malaysia, Singapura, Hongkong, Thailan,dan Filipina (Hernandeset al.2015, Nadchatram, 2005, Chew et al. 1999, Sun et al. 2004, Mariana et al. 2000, de las Lliagas et al.2005).Di Turki, salah satu negara Eropa, ditemukan prevalensi TDR sebesar 72,2\% (Aykut et al 2016). Faktor yang mempengaruhi prevalensi TDR di Turki ialah letak topografi rumah, frekuensi meenggunakan vacum cleaner per bulan, jumlah anggota keluarga, dan kelembapan relatif. Jumlah populasi TDR maksimum ditemukan pada musim panas, sedangkan selama musim gugur jumlah TDR menurun.

Spesies D. pteronyssinus merupakan spesies TDR yang mendominasi, terutama pada iklim tropik, karena D. pteronyssinus dapat bertahan hidup pada kelembapan relatif minimal $70 \%$ dengan suhu 
25oC. Berbeda dariD. farinae, tungau ini dapat bertahan hidup padakelembapan relatif $50 \%$ (Arlian et al, 1999, Crowther et al, 2006). Salah satu penyebab D. pteronyssinus sukses di daerah iklim tropis karena tubuh tungau tersebut dilindungi oleh lapisan kulit sehingga tidak terjadi dehidrasi yang berlebihan. D. pteronyssinus juga mempunyai sepasang kaki depan yang dilengkapi kelenjar (Supraeuxal gland) yang berfungsi untuk menangkap air dari udara sehingga dalam keadaan kering tungau tersebut tidak kekurangan air (Whartlon, 1977). Selain itu, D. pteronyssinus mempunyai perkembangbiakan yang lebih cepat dibandingkan tungau lainnya (Arlian et al, 1999).

Hasil penelitian ini memperlihatkan bahwa spesies TDR yang ditemukan pada habitat tidak hanya tunggal, tetapi bisa dalam bentuk campuran. Di kasur kapuk yang merupakan habitat alami ditemukan spesies tunggal TDR paling banyak dibandingkan habitat lainnya di dua lokasi penelitian. Keberadaan spesies tunggal atau campuran TDR di dalam satu habitat menunjukkan bahwa spesies TDR dapat hidup bersama-sama. Hasill penelitian ini juga memperlihatkan keberadaan spesies TDR berlimpah di dua lokasi penelitian dan spesies D. pteronyssinus lebih dominan.

Metode untuk mendiagnosis tungau dari debu sudah banyak dikembangkan. Dalam penelitian ini, identifikasi spesies TDR pada debu rumah menggunakan teknik pemeriksaan langsung. Beberapa keuntungan teknik pemeriksaan langsung ialah murah, sederhana, dan cepat. Teknik flotasi dengan menggunakan larutan $\mathrm{NaCl}$ jenuh membutuhkan waktu yang relatif lama (minimal 24 jam). Teknik ELISA untuk mendeteksi TDR pada debu rumah relatif mahal (Sander et al 2012).Untuk penelitian yang memiliki dana yang sedikit, teknik pemeriksaan langsung merupakan teknik yang terbaik dibandingkan dengan teknik lainnya.

Dalam penelitian ini, kasur merupakan faktor risiko untuk TDR (OR=1.99 95\% CI 1.06-3.72). Schei et al (2002), di Norway Utara, USA, melaporkan bahwa 40,5\% TDR ditemukan pada debu kasur busa tanpa penutup dan 26,3\% TDR pada kasur busa dengan penutup. Nilai OR untuk tinja TDR pada kasur busa dengan penutup sebesar 4,0 (95\% CI=1.1-15.1) dan pada kasur busa tanpa penutup adalah OR $=8.1(95 \% \mathrm{CI}$ 1.8-36.9). Kasur digunakan sebagai tempat tidur akibatnya banyak serpihan kulit manusia ditempat tersebut. Oleh karena itu, pada debu kasur banyak ditemukan TDR dibandingkan dengan pada debu yang diperoleh dari tempat lainnya.

Korsgaard(1998) menyatakan TDR membutuhkan makanan dari serpihan kulit manusia (0,5-1g/orang) dan ribuan TDR dapat bertahan hidup selama beberapa bulan dengan jumlah serpihan kulit manusia sebanayk 0,25 g . Jika tidak ada serpihan kulit manusia, TDR dapat memakan bakteri, jamur, dan kulit binatang lainnya. Pada tempat tertentu, seperti ventilasi rumah, sofa, dan karpet,ketersediaan serpihan kulit manusia sebagai makanan TDR kurang banyak dibandingkan dengan pada kasur. Selain itu, kasur yang terbuat dari serat kapuk merupakan tempat yang cocok untu TDR karena pada serat kapuk banyak terdapat jamur (mold). Jamur tersebut membantu untuk memecahkan dan melembutkan serpihan kulit manusia (Asselt, 1999).

Frekuensi membersihkan kasur yang dilakukan oleh responden di Pamulang dan Pasar Rebo hanya 1-2 $\mathrm{x}$ sehari tidak memperlihatkan hasil perbedaan yang bermakna $(p>0,05)$ pada keberadaan TDR. Hal itu disebabkan oleh rancangan penelitian ini yang menggunakan cross-sectional. Tidak ada tindak lanjut dalam penelitian ini.Berbeda dari hasil penelitian di Norway Utara oleh Schei et al. (2002), yaitu membersihkan kasur merupakan faktor pencegah terhadap keberadaan TDR $(\mathrm{OR}=0,11$ 95\% CI=0,02-062). Untuk memperlihatkan pengaruh yang signifikanmaka lebih baik menggunakan rancangan eskperimen, yaitu ada kelompok kontrol dan perlakuan (membersihkan kasur).

Memberishkan kasur, lantai rumah, ventilasi rumah, dan lain-lain merupakan salah satu upaya untuk mengendalikan TDR. Selain itu, menggunakan akarisida juga dapat mengendalikan TDR. Meskipun demikian, upaya-upaya tersebut mempunyai pengaruh yang sementara. Oleh karena itu, Departemen 
Parasitologi, Fakultas Kedokteran, Departemen Teknik Kimia, dan Departemen Metalurgi dan Material, Fakultas Teknik Universitas Indonesi akan membuat suatu prototipe, yaitu sarung kasur, sarung bantal, dan selimut yang ditutup dengan nano komposit (Titania Dioksida) sehingga TDR tidak dapat melintasi (keluar dan masuk) sarung dan selimut tersebut. Prototype tersebut didasarkan bahwa sarung kasur, sarung bantal, dan selimut memiliki pori-pori sebesar $1000 \mu$, sedangkan TDR berukuran $300 \mu$. Oleh karena itu TDR dapat keluar dan masuk melalui pori-pori tersebut. Dengan adanya prototype tersebut dapat memberikan keamanan untuk penderita asma.

\section{KESIMPULAN}

Spesies TDR yang ditemukan di Pamulang dan Pasar Rebo ialahD.pteronyssinus, D.farinae, danG.destructor. Prevalensi TDR di Pamulang lebih besar dibandingkan dengan di Pasar Rebo. Keberadaan TDR ditemukan di berbagai bagian rumah, baik rumah dengan status kontrakan dan pribadi. Kasur dan lantai kamar tidur merupakan faktor risiko TDR. Di daerah perkotaan tersebut, rumah penduduk telah tercemar debu rumah yang mengandung TDR.

\section{DAFTAR PUSTAKA}

Asher MI, Montefort S, Bjorksten B, et al.ISAAC Phase Three Study Group. Worldwide time trends in the prevalence of symptoms of asthma, allergic rhinoconjunctivitis, and eczema in childhood: ISAAC phases one and three repeat multicountry crosssectional surveys. Lancet 2006; 368: 733-43.

Arshad SH (2010) Does exposure to indoor allergens contribute to the development ofasthma and allergy? Curr Allergy Asthma Rep 10: 49-55.

Arlian LG, Neal JS, Vyszenski-Moher DL. Reducing relative humidity to control the house dust mite Dermatophagoides farinae.J Allergy ClinImmunol 1999;104:852-6.

Asselt, L Van (1999). Interactions between domestic mites and fungi. Indoor \& Built Envir $8: 216-220$.
Aykut M, Erman OK, Doğan S. Variability in Population Density of House Dust Mites of Bitlis and Muş, Turkey.J Med Entomol. 2016.

Aulung A, Djaja B, Widjaja M, Tjokronegoro A. Penggunaan teknik isolasi pada penggunaan tungau debu rumah. Medika1986;(2):161-165.

Baratawidjaja IR, Baratawidjaja PP, Darwis A, Yi FC, Chew FT, Lee BW, et al. Mites in Jakarta homes. Allergy. 1998; 53: 1226-7.

Brussee JE, Smit HA, van Strien RT, Corver K, Kerkhof M, et al. (2005) Allergen exposure in infancy and the development of sensitization, wheeze, and asthma at 4 years. J Allergy Clin Immunol 115: 946-952.

Carlsten C, Ferguson A, Dimich-Ward H, Chan H, DyBuncio A, et al. (2011) Association between endotoxin and mite allergen exposure with asthma and specific sensitization at age 7 in high-risk children. Pediatr Allergy Immunol 22:320-326.

Chew FT, Zhang L, Ho TM, Lee BW. House dust mite fauna of tropical Singapore. Clin Exp Allergy. 1999; 29: 201-6.

Crowther D, Wilkinson T, Biddulph P, Oreszczyn T, Pretlove S, Ridley I.A simple model for predicting the effect of hygrothermal conditions on populations of house dust mite Dermatophagoides pteronyssinus (Acari:Pyroglyphidae). Exp Appl Acarol. 2006; 79: 127-148.

Custovic A, Taggarat SCO, Francis, HC, Chapman MD, Woodcock A. Exposure of house dust mite allergens and the clinical activity of asthma. J Allergy Clin Immunol 1996;98:6472.de las Llagas LA, Mistica MS, Bertuso AG. House dust mites collected from houses of persons with respiratory allergies. Philippine Entomologist. 2005; 19: 193-200.

Hernandez-Cadena L, Zeldin DC, BarrazaVillarreal A, Sever ML, Sly DP, London SJ, Escamilla-Nunez M C, Romieu I. Indoor determinants of dustborne allergens in Mexican homes.Allergy Asthma Proc 36:130 -137, 2015. 
Henszel Ł1, Kalisińska E, Kosik-Bogacka D, Kuźna-Grygiel W. Acarologicalfaunistic and statistical analysis of dust from various compartments of human dwellings in northwestern Poland.WiadParazytol. 2010;56(1):51-7.

Jaquet A. New insight into the molecular basis of the house dust mite-induced allergy response. The Open Allergy Journal 2009;2:38-44.

Korsgaard, J.House-dust mites and asthma. A review on house-dust mites as a domestic risk factor for mite asthma. Allergy 1998, 53 Supplement $48: 77-83$.

Lim FL, Hashim Z, Than LTL, Md Said S, Hashim JH, Norbäck D. Asthma, Airway Symptoms and Rhinitis inOffice Workers in Malaysia: Associations with House Dust Mite (HDM) Allergy, Cat Allergy and Levels of House Dust Mite Allergens in Office Dust. PLoS ONE 10(4): e0124905.

Mariana A, Ho TM, Sofian-Azirun M, Wong AL. House dust mite faunain the Klang Valley, Malaysia. Southeast Asian J Trop Med Pub Health.2000; 31:712-21.

Nadchatram, M. House dust mites, our intimate associates.Tropical Biomedicine 22(1): 23-37 (2005)

Sander I, Zahradnik E, Kraus G, Mayer S, Neumann H-D, et al. (2012) Domestic Mite Antigens in Floor and Airborne Dust at Workplaces in Comparison to Living Areas: A New Immunoassay to Assess Personal Airborne Allergen Exposure. PLoS ONE 7(12): e52981. doi:10.1371/journal.pone.0052981

Santoso H. The value of a single skin prick testing for specific IgE Dermatophagoides pteronyssinus to distinguish atopy from nonatopic asthmatic children in the tropics. Asian Pac J Allergy Immunol. 1998; 16:69-74.

Schei MA, Hessen JO, Lund E. House-dust mites and mattresses.Allergy 2002: 57: 538542.

Sun BQ, Wu A, Chan A, Chik S, Wong D, Zhong
NS. House dust mite allergen (Derp1 and Blot5) levels in asthmatics' home in Hongkong. Chin Med Sci J. 2004; 19:185-8.

Thomas WR, Smith WA, Hales BJ, Milis KL, O'Brien RM. Characterization and immunobiology of house dust mite allergens. Int Arch Allerg Immunol. 2002;129:1-18.

Thomas WR. Geography of house dust mite allergens.Asian Pac J Allergy Immunol 2010;28:211-24.

Voorhorst R, Spieksma FTHM, Varekamp H. House dust at atopy and the house dust mite. Staflen's Scientific Publishing Company. Leiden. 1969

Whartlon CW. 1-uniriii/u K'V. Supraeuxal gkmd secretion as source of fresh water for Aearidci. Ac:ulilogiu 1977;19:112-6.

Wright GR, Howieson S, McSharry C, McMahon AD, Chaudhuri R, Thompson J,et al.Effect of improved home ventilation on asthma control and house dust mite allergen levels.Allergy 2009: 64: 1671-1680. 